\title{
Evaluating Outcomes from Stakeholders' Perception: Evidence from an Irrigation Project in Nigeria
}

\author{
Daniel Adeoluwa Adeniyi \\ Institute for Social Development, University of the Western Cape (UWC), South Africa \\ adeolu.adeniyi@yahoo.com \\ and \\ Mulugeta F. Dinbabo ${ }^{1}$ \\ Institute for Social Development, University of the Western Cape (UWC), South Africa \\ DOI//http://dx.doi.org/10.4314/gjds.v13i2.2
}

\begin{abstract}
The need for the appreciation of values and knowledge diversity has contributed to the increasing relevance of stakeholder participation in the monitoring and evaluation (M\&E) of development projects. Using mixed methods research design and indicators, this paper assesses the outcomes of the participatory monitoring and evaluation (PME) process of the Tada Shonga Irrigation Project, Kwara State, Nigeria. A total of 103 respondents were randomly selected for questionnaire administration, and 5 respondents interviewed for the study. An Outcome Perception Index (OPI) was developed to assess stakeholders' perception of the extent to which the project had met its objectives. The study found out that the project's PME process was deficient, and the outcomes of the project and its PME process had been a mixed bag. The study further established a significant relationship between the deficient PME process of the project and project outcomes, although the relationship is indicative, rather than proof of a possible causal relationship. This was corroborated by the qualitative analysis which highlighted other critical factors affecting project outcomes. The study concluded that stringent M\&E framework must be imbued in government policies to ensure success and sustainability of projects and programmes.
\end{abstract}

Keywords: Participation, Monitoring, Evaluation, Programme, Development

\section{Introduction}

Participatory Monitoring and Evaluation (PME) entails a joint and collaborative effort among stakeholders such as farmers, researchers, government officials or extension

1. Corresponding author: Mulugeta F. Dinbabo

26 | GJDS, Vol. 13, No. 2, October, 2016 
workers to undertake a systematic monitoring and evaluation of one or more research or development activities (Vernooy et al., 2003). In general, PME, also known as stakeholder evaluation, participatory evaluation or collaborative monitoring and evaluation, has been identified as a valuable tool for ensuring the success and sustainability of development programmes and projects due to its emphasis on stakeholder participation (Dinbabo, 2005).

Indeed, the active engagement of multiple stakeholders remains the major feature of participatory evaluation. According to Heck et al. (2011), participatory approach is potentially effective for the enhancement of evaluation capacity, increment of credibility and results acceptance, thus strengthening relationships between local stakeholders and managers. Participatory evaluation is also described as a major tool for transformation, stimulating the analytical capabilities of all participating stakeholders, while also encouraging mutual acknowledgment of different perspectives (Mathie \& Greene, 1997).

In participatory evaluation, stakeholders are saddled with the responsibility of developing indicators for measuring change and progress towards achievement of objectives. This study evaluates the outcomes of the PME process of the Tada Shonga Irrigation Project, as well as that of the project in general through the development of community indicators through stakeholder perceptions.

Nigeria typifies a case of poverty amidst plenty. Despite the profusion of resources at its disposal, Nigeria is still dawdling in terms of socio-economic development. Indeed, several allusions have been made to Nigeria's significant progress in terms of economic growth. The World Bank (2013) posits that Nigeria's GDP has grown at an average rate of 8 per cent over the last decade. The recent rebasing of Nigeria's GDP raised the size of her economy by 75 per cent, thus making the country the biggest economy in Africa and the $28^{\text {th }}$ largest economy in the world (Deutsche Bank Research, 2014, National Bureau of Statistics, 2014). However, the impressive economic growth has not translated into the improvement of lives of Nigerians. The nation is struggling to develop as it has a high and persisting poverty rate and was unable to reach the Millennium Development Goal (MDG) poverty reduction target by 2015. According to the NBS (2010), about 61 per cent of Nigerians still live below the one dollar poverty line as at 2010 and this was an increase from 51.6 per cent recorded in 2004. The poverty rate has however increased to 64.2 per cent as at 2013 (World Bank, 2013:9). As a result of the foregoing, it has been the onus of the Nigerian government to initiate development policies, projects and programmes in a bid to curtail the persisting high level of poverty in Nigeria.

The River Basin Development Authorities (RBDAs) were established by the Federal Government of Nigeria in 1977 in order to improve agricultural production and ensure food security and poverty reduction in the nation (Akindele \& Adebo, 2004; Daneji, 
2011). The establishment of the RBDAs represents a major irrigation policy instrument initiated for the exploitation of the vast water resources for fishing and agricultural purposes. A major rationale for the establishment of the RBDAs was the need to encourage large-scale agriculture in order to boost food production. Along similar lines, the institution of the RBDAs was also necessitated in a bid to stem the tide of the short rainy seasons that have restricted crop production in many parts of the country (Daneji, 2011). The nation presently has 12 RBDAs in operation covering different parts of the country. The Tada Shonga Irrigation Scheme is operated by the Lower Niger River Basin Development Authority (LNRBDA).

The Tada Shonga Irrigation Project, which is conceived as a pilot public-private partnership, has a proposed gross area of 2700 hectares for the irrigation scheme which lies to the right bank of River Niger within the flood plain downstream of Jebba, and is appropriate for the cultivation of rice (Federal Ministry of Water Resources, 2006). The scheme is designed as a lift irrigation system, involving the direct lifting of water from the River Niger and delivery through a network of canals, while flood control dykes will also be constructed. The scheme is subdividing the numerous hectares of land and is allocating these lands to farmers to cultivate rice (Gunda et al., 2013).

The public irrigation scheme in Nigeria has only recorded limited success in meeting the target set for them. The FMWR (2006) posits that the sector's performance has not had the expected impact on national food security, economic growth and employment opportunities. One of the reasons for this failure is the apparent lack of adequate monitoring and evaluation. As argued by Adebayo et al. (2009), inadequate monitoring and evaluation in Nigeria are constraints which have resulted in situations where policies and programmes have lost sight of their aims. This study, through the development of community indicators and stakeholder perceptions, intends to evaluate the outcomes of the PME process, and the project in general.

\section{Literature Review}

Participatory Monitoring and Evaluation (PME) represents an attempt to incorporate participation into the monitoring and evaluation process. PME entails an 'involvement of multiple stakeholders in the design and implementation of observing, systematising and interpreting processes as a basis for joint decisions about improving their joint activities' (Bayer \& Waters-Bayer, 2002:5). Participation is certainly the key distinguishing characteristic of PME, and this clearly differentiates it from conventional approaches to M\&E (Chouinard; 2013; Cullen et al., 2011; Estrella, 2000; Estrella \& Gaventa, 1998; Holte-McKenzie et al., 2006; Jacobs et al., 2010). 
The importance and relevance of PME lies in its ability to measure change for differing purposes. PME approaches are used for improving project planning, implementation and assessment, impact assessment, organisational strengthening and institutional learning, improving public accountability, understanding and negotiation of stakeholders' perceptions, as well as for informed policy decisions (Estrella, 2000; Estrella \& Gaventa, 1998). Perhaps the greatest strength is the one that ensures that PME serves as both the means and end of empowerment. As noted by Jacobs et al. (2010), the means and end of empowerment is achieved through PME when it leads to real reflection, learning and devotion.

Despite the significance of PME, the approach has however not come without its own attendant limitations. As Jacobs et al. (2010) observed, the problems associated with PME are also analogous to those associated with wide participatory practice, and these include domination by local elites, exclusion, the generation of subjective and sometimes unreliable data, as well as the difficulty in aggregating qualitative data or drawing general conclusions from such data. Furthermore, institutional incentives are often lacking owing to the fact that the participatory process could be time consuming, and managers and donors want quick results (Jacobs et al., 2010), whilst participatory processes are rigorous and sometimes lack validity (Bradley et al., 2002).

Evidence abounds of the use of PME to evaluate project outcomes in different parts of the world. In Latin America, Blauert and Quintanar (2000) undertook a participatory stakeholder evaluation of the Mexican Centre of Alternative Technologies (CETAMEX), a non-governmental organisation involved in farmer-to-farmer approach to agriculture using subsistence and indigenous farming techniques. Utilising a combination of methodologies including participatory rural appraisal, ethnography, social auditing and grassroots development frameworks, they indicated that PME led to improved human relations and leadership qualities, improved performance and impact, while also contributing to institutional learning.

In Asia, Cramb et al. (2004) conducted a participatory assessment of a smallholder project in Central Vietnam using PRA techniques within a rural livelihoods framework to assess household livelihoods. They found that while there were marked differences in the physical stock of capital owned by different households which had an effect on the livelihood strategies pursued by respective households, there was an improved understanding of livelihood strategies which would be beneficial for project participants as the project progresses.

Fraser et al. (2006) carried out a comparative PME in three different continents. They assessed the impact of participatory processes in environmental management and the identification of sustainability indicators in three different case studies, British 
Columbia in Canada (North America), Kalahari Rangelands in Botswana (Africa) and Guernsey in the United Kingdom (Europe). Fraser et al. (2006) concluded that the comparative assessments between the three case studies validated the participatory methods as comprehensive and long lists of indicators were generated. They also discovered that flexibility is germane when choosing the scale at which monitoring and decision making takes place, and that the process of selecting indicators led to increased empowerment of the communities.

Franzel et al. (2008) worked on a collaborative M\&E in Western Kenya involving the organisation of several stakeholder workshops, as well as organisational-level surveys where each organisation collected and presented information, which included the management practices each organisation was promoting and farmers' views on the pros and cons of such management practices. The study established that collaborative M\&E led to increased mutual learning among organisations, improved M\&E skills, enhanced partnerships, and increased social capital. Zerfu and Kebede (2013) reported on the implementation of PME in farmer field schools in Zanzibar, Tanzania and the PME process involved a collaborative process among stakeholders. They found that the tracking of technology uptake was made possible through PME, and that PME led to improved decision making in the project.

Njuki et al. (2008) used PME to evaluate the Enabling Rural Innovation initiative, a community development project in Malawi. In what they referred to as a communitydriven PME approach, community indicators were developed with farming communities to evaluate the extent to which project objectives had been achieved. The indicators were aggregated using scores and a Likert scale to assess the communities' perceptions of the project impact and outcomes. They found that the project led to increased income for households, reduction in food insecurity and women empowerment.

In Nigeria however, studies or reports on the use of PME are few and far between. Douthwaite et al. (2007) carried out a participatory evaluation of a weed control project on farms in Northern Nigeria. The research typifies a fusion of stakeholder participation with the impact pathway evaluation method adopted in the study, as it continually incorporated farmer modifications identified through the M\&E components into the project. The result was an enhancement in the livelihoods of farmers that adapted the weed control strategy. Ijaiya (2006) combined quantitative and qualitative research methodologies to ascertain the influence of beneficiary participation on the performance of the Directorate of Food, Road and Rural Infrastructure's (DFRRI) borehole water projects in Offa, Kwara State. Qualitative information on the performance of the projects was obtained from beneficiaries using the participatory assessment method through focus group discussions. The study found that beneficiaries were not involved during the construction of the project as that was the exclusive 
preserve of the government and agency in charge. The study however indicated that beneficiaries participated in the design, maintenance and repairs of the projects and their participation had a positive effect on project performance. There is however an apparent lack of empirical research on the application of PME to measure irrigation project outcomes in Nigeria. This study explores that as it focuses on the stakeholder assessment of project outcomes of the Tada Shonga Irrigation Project in Kwara State, Nigeria using PME.

\section{Methodology}

The study used the mixed-methods approach for the empirical research. Interviews were conducted with relevant stakeholders and a questionnaire survey was carried out on beneficiaries. Blauert and Quintanar (2000) opine that PRA can be modified to suit local contexts in the analysis of stakeholder perceptions. The study used PRA and its tools such as farm profiles, matrix ranking and seasonal calendar to identify the outcome indicators as series of meeting were conducted with both the LNRBNDA staff and project beneficiaries. This served as the basis and guide for the questions drawn up for the semistructured interview and questionnaire survey.

For the purpose of the study, different sampling techniques were adopted to select samples out of the population for the semi-structured interviews and questionnaire administration. With respect to the latter, systematic random sampling was used to select respondents sampled. Systematic sampling is a sampling technique which entails the systematic selection of every ' $k t h$ ' element in the population. Information obtained from LNRBDA indicates that there were about 330 beneficiaries in the Tada Shonga Irrigation Project. The first respondent was therefore selected at random on the farm sites and subsequent subjects were every third beneficiary. In other words, one out of every three beneficiaries was selected for questionnaire administration. Using this method, a total of 110 beneficiaries were sampled. However, out of the 110 questionnaires administered, 103 questionnaires were returned and this constituted the responses that made up the analysis.

Purposive sampling was utilized to select respondents interviewed. In purposive sampling, the subjects are selected owing to some characteristics. To this end, semistructured interviews were conducted with respondents that are knowledgeable about the project and are active participants in the direct implementation of the scheme. A total number of five respondents comprising implementation agency staff and beneficiaries were interviewed.

The study utilizes indexes which represent composite measures of variables as well as efficient data analysis and data reduction devices that allow for the summarisation 
of several indicators into a single numerical score (Babbie, 2007). Literature abounds on the usage of varieties of index measures in research (see for example, the modified Consumer Price Index of Bryan and Cecchetti (1993); the Economic Security Index designed by Hacker et al. (2013); and UNDP's Human Development Index (UNDP, 2013)). Following Wharton and Baron (1987) that developed an index measure to assess work satisfaction among workers, and Afon (2009) who developed a satisfaction index to examine residents' satisfaction of the activities of two local planning authorities in Nigeria, this study developed an Outcome Perception Index (OPI) to assess beneficiaries' perceptions of the outcome of the PME process and the project.

The OPI was computed by first assigning values from 1 to 5 to the ordinal responses (Likert's scale responses) of the beneficiaries, with a higher value signifying stronger agreement to the question that made up the variable. The total weight value for each of the variables (SWV) was thereafter computed by summing the product of the number of responses for each rating to a variable and the respective weight value. It is expressed mathematically thus: Where:

$$
\begin{aligned}
& \text { SWV.= summation of the total weight value; } \\
& \mathrm{P}_{\mathrm{i}}=\text { = number of respondents to rating } \mathrm{i} ; \\
& \mathrm{V}_{\mathrm{i}}=\text { = weight assigned to a response. }
\end{aligned}
$$

The index (I) to a variable is determined by dividing the SWV by the summation of the respondents to each of the five ratings of the variable and is expressed as:

The mean index, denoted as is derived by summing up the index for each variable and dividing it by the number of the identical variables. It is computed mathematically thus:

Where $\mathrm{n}=$ total number of identical variables.

The Kruskal-Wallis test is used to examine the difference in beneficiaries' views of the project outcomes. Kruskal-Wallis is a non-parametric test designed for the detection of differences among population which requires no assumption about the shape of the population distribution (Aczel \& Sounderpandian, 2009). Data gotten from the semistructured interviews were analysed using thematic content analysis in order to draw out important patterns and common themes, while also deepening the understanding of project outcomes. 


\section{Results and Discussion}

The different farmer groups operating in the scheme were identified and these are presented in Table 1. Findings reveal that 84.5 per cent belonged to a farmer group or association, while 15.5 per cent of the total respondents did not belong to any farmer association. Furthermore, the table indicates that fifteen (14.6 per cent) respondents were members of the farmers' group known as Ganya Bariki Shonga, twenty-five (24.3 per cent) respondents were affiliated to Shonga Dry Season Farmers' Association, and forty-seven (45.6 per cent) respondents belonged to the Water Users' Association.

Table 1: Identified farmer groups

\begin{tabular}{|l|l|l|}
\hline Name of farmer groups respondents belonged to & Frequency & Percentage \\
\hline Water Users' Association & 47 & 45.6 \\
\hline Shonga Dry Season Farmers' Association & 25 & 24.3 \\
\hline Ganya Bariki Shonga & 15 & 14.6 \\
None & 16 & 15.5 \\
\hline Total & 103 & 100 \\
\hline
\end{tabular}

The PME process of the project was also assessed through the analysis of beneficiaries' perception of their level of involvement in PME process activities. Beneficiaries were asked to rate their perceived involvement in each of the PME process activities using a Likert's scale indicator. The Likert's scales used for the rating were 'very involved' (VI), 'involved' (I), 'somewhat involved' (SI), 'not involved' (NI) and 'not at all involved' (NAI). Analysis of beneficiaries' perception of the PME process presented in Table 2 indicates that beneficiaries' perception of their level of involvement in outcomes choosing, the selection of indicators for M\&E, data collection and data analysis were 64.1 per cent, 93.2 per cent, 76.7 per cent and 61.2 per cent respectively, and these were significantly above average. Respondents' perception of their level of involvement in the determination of findings was nearly evenly divided as 49.5 per cent of the beneficiaries sampled stated that they were not involved in the determination of findings. It is thus not surprising that 69.9 per cent of the respondents stated that they were not involved in the decisions taken after M\&E as almost half of them were not involved in the determination of findings which automatically is the precursor to the making of decisions based on the M\&E findings. Also, 62.1 per cent of the respondents stated they were not involved in the initial design of the project's M\&E. 
Table 2: Level of involvement in PME process activities

\begin{tabular}{|l|l|l|l|l|l|l|}
\hline \multicolumn{7}{|c|}{ Beneficiary Perception of their Level of Involvement } \\
\hline $\begin{array}{l}\text { PME Process } \\
\text { Activities }\end{array}$ & $\begin{array}{l}\text { Very } \\
\text { Involved }\end{array}$ & Involved & $\begin{array}{l}\text { Somewhat } \\
\text { Involved }\end{array}$ & $\begin{array}{l}\text { Not } \\
\text { Involved }\end{array}$ & $\begin{array}{l}\text { Not at all } \\
\text { Involved }\end{array}$ & Total \\
\hline Initial design of M\&E & $1(1.0 \%)$ & $4(3.9 \%)$ & $34(33.0 \%)$ & $37(35.9 \%)$ & $27(26.2 \%)$ & $103(100 \%)$ \\
\hline $\begin{array}{l}\text { Outcomes choosing } \\
\text { for M\&E }\end{array}$ & $1(1.0 \%)$ & $33(32.0 \%)$ & $32(31.1 \%)$ & $36(35.0 \%)$ & $1(1.0 \%)$ & $103(100 \%)$ \\
\hline $\begin{array}{l}\text { Selection of } \\
\text { indicators for M\&E }\end{array}$ & $35(34.0 \%)$ & $39(37.9 \%)$ & $22(21.4 \%)$ & $5(4.9 \%)$ & $2(1.9 \%)$ & $103(100 \%)$ \\
\hline $\begin{array}{l}\text { Data collection for } \\
\text { M\&E }\end{array}$ & $24(23.3 \%)$ & $54(52.4 \%)$ & $22(21.4 \%)$ & $3(2.9 \%)$ & - & $103(100 \%)$ \\
\hline $\begin{array}{l}\text { Data analysis for } \\
\text { M\&E }\end{array}$ & $5(4.9 \%)$ & $24(23.3 \%)$ & $33(32.0 \%)$ & $40(38.8 \%)$ & $1(1.0 \%)$ & $103(100 \%)$ \\
\hline $\begin{array}{l}\text { Determination of } \\
\text { findings from M\&E }\end{array}$ & - & $14(13.6 \%)$ & $38(36.9 \%)$ & $44(42.7 \%)$ & $7(6.8 \%)$ & $103(100 \%)$ \\
\hline $\begin{array}{l}\text { Decisions taken after } \\
\text { M\&E findings }\end{array}$ & $1(1.0 \%)$ & $5(4.9 \%)$ & $25(24.3 \%)$ & $36(35.0 \%)$ & $36(35.0 \%)$ & $103(100 \%)$ \\
\hline
\end{tabular}

Findings from interviews conducted supported the view that beneficiaries were not involved in the analysis of data from the M\&E, as a participant stated the following:

What they know we share it, bring it to the office or to any research station that would analyse it and come out with a good farming system and put them to practice (P3: LNRBDA staff, September 4, 2014).

Also, another respondent explained:

When we collect some of the data together, it is true that although we already know some of the problems, the (LNRBDA) staff sometimes go with some data and come back to tell us why our harvest is like that ( $\mathrm{P}_{5}$ : Beneficiary, September 4, 2014).

Evidently, beneficiaries were not involved in the data analysis for the M\&E, as staff of the implementing agency brought the data obtained from the field to their project office for analysis. The non-involvement of beneficiaries in the data analysis is congruent with the findings in the quantitative analysis. It is thus conclusive from the foregoing analysis that the PME process of the project was deficient as all the process activities were not entirely participatory.

The Outcome Perception Index (OPI) entails the assessment of beneficiaries' views of what has been the resultant effect of the PME process of the project in particular, and the scheme in general. It represents the analysis of the ratings of the beneficiaries' perceptions of some outcome measures and this is presented in Table 3. Beneficiaries 
were asked to rate their level of agreement with the outcome measures using a Likert's scale. The Likert's scale used for the rating were strongly agree (SA), agree (A), somewhat agree (SWA), disagree (D), strongly disagree (SD) which were respectively assigned a weight value of 5,4,3,2 and 1. The procedure for the computation of the sum of the total weight value (SWV), outcome perception index (OPI), and mean outcome perception index ( follows the same process explained in the methodology section, where the closer the OPI is to five, the higher the achievement of such outcome. The analysis of respondents' perceptions of the project outcomes shows that the overall perception of the outcome of the project and PME process was a little above average. The aggregate level of the outcome perception measure is 3.03, a figure that is slightly higher than 'somewhat agree' that was rated ' 3 '. Further analysis indicates that the project and its PME process have had mixed outcomes, as five outcome measures have positive deviations about and this is also presented in Table 3.

The table shows that the outcome perceived by the beneficiaries to be the most achieved, is the increase in confidence to approach extension workers to share their problems, thoughts and opinions with a positive deviation of 1.23. Also, the ability to solve agricultural problems through experimentation ranked second in the beneficiaries' perceptions of the outcome that has been achieved with a positive deviation of 0.43 . Other outcome measures with positive deviations were the change in natural resources utilisation as a result of $M \& E$, the increase in farmer organisations' ability to influence the project and the migration of people to Tada Shonga as a result of the project, with respective deviations of $0.25,0.14$ and 0.06 . 
Table 3: Outcome perception index

\begin{tabular}{|c|c|c|c|c|c|c|c|c|}
\hline \multirow[b]{2}{*}{ Outcome Measures } & \multicolumn{5}{|c|}{ Rating and Weight Value* } & \multirow[b]{2}{*}{ SWV } & \multirow[b]{2}{*}{ OPI } & \multirow[b]{2}{*}{$(\mathrm{OPI}-)$} \\
\hline & $\begin{array}{l}\text { SA } \\
(5)\end{array}$ & $\begin{array}{l}\text { A } \\
(4)\end{array}$ & $\begin{array}{l}\text { SWA } \\
\text { (3) }\end{array}$ & $\begin{array}{l}\mathrm{D} \\
(2)\end{array}$ & $\begin{array}{l}\text { SD } \\
\text { (1) }\end{array}$ & & & \\
\hline $\begin{array}{l}\text { Increase in farmer organisations' } \\
\text { ability to initiate activities relevant } \\
\text { to the project }\end{array}$ & 6 & 32 & 38 & 27 & - & 326 & 3.17 & 0.14 \\
\hline $\begin{array}{l}\text { Change in natural resources } \\
\text { utilisation as a result of } \mathrm{M} \& \mathrm{E}\end{array}$ & 12 & 28 & 40 & 23 & - & 338 & 3.28 & 0.25 \\
\hline $\begin{array}{l}\text { Increase in land area utilized for } \\
\text { agricultural production }\end{array}$ & 3 & 12 & 27 & 28 & 33 & 248 & 2.41 & -0.62 \\
\hline $\begin{array}{l}\text { Increase in economic activities } \\
\text { in Tada Shonga as a result of the } \\
\text { project }\end{array}$ & 2 & 6 & 66 & 28 & 1 & 289 & 2.81 & -0.22 \\
\hline $\begin{array}{l}\text { Migration of people to Tada Shonga } \\
\text { as a result of the project }\end{array}$ & 14 & 27 & 23 & 34 & 18 & 318 & 3.09 & 0.06 \\
\hline $\begin{array}{l}\text { Ability to solve agricultural } \\
\text { problems through experimentation }\end{array}$ & 10 & 43 & 28 & 20 & 2 & 348 & 3.38 & 0.43 \\
\hline $\begin{array}{l}\text { Confidence to approach extension } \\
\text { workers to share problems, } \\
\text { thoughts and opinions }\end{array}$ & 56 & 21 & 24 & 1 & 1 & 439 & 4.26 & 1.23 \\
\hline $\begin{array}{l}\text { Improvement of individuals' and } \\
\text { households' lives as a result of } \\
\text { participation in the project }\end{array}$ & 4 & 6 & 44 & 30 & 19 & 255 & 2.48 & -0.55 \\
\hline $\begin{array}{l}\text { Increased production of crops as a } \\
\text { result of knowledge gained from the } \\
\text { scheme }\end{array}$ & 4 & 20 & 20 & 32 & 27 & 251 & 2.43 & -0.60 \\
\hline Total & & & & & & & 27.31 & \\
\hline
\end{tabular}

On the other hand, the outcome perceived by beneficiaries to be the least achieved was the increase in the land area utilized for agricultural production, with a negative deviation of - 0.62 . The majority of the respondents also indicated that the PME process had not led to an increase in the production of crops as the outcome measure had a negative deviation of - 0.60 , while the majority of the beneficiaries were of the opinion that the PME process and the project in its entirety had not led to an improvement of their lives and that of their households, with the outcome measure having a deviation of - 0.55. Furthermore, the majority of the beneficiaries indicated that the project had not led to an increase in economic activities in Tada Shonga, as the outcome measure has a negative deviation of -0.22 . 
Furthermore, it clearly emerged from the comments from the interviews conducted that the PME process generally had mixed impacts on project outcomes. In other words, the PME process resulted in both positive and negative project outcomes. Highlighting the positive outcome of the PME process, one respondent stated:

Whenever we come together to do $M \& E$, what happens is we see that these farmers have improved in the way they choose their seeds and even if something is wrong, they are now able to identify the problem (P1: LNRBDA staff, September 3, 2014).

The above statement is an indication that beneficiaries had become more adept in the selection of better seedlings and problem identification as a result of the PME process. This further reinforces the 'knowledge generation' feature of participation. In a similar vein, the PME process of the project aided the transfer of knowledge among farmers, as well as between farmers and LNRBDA staff, as a respondent indicated:

....even the local farmers around, because most of these farmers are immigrant Hausas, whatever they know where they come from, they try to make it indigenous around this place and the local farmers too are also having (it) ( $\mathrm{P}_{3}$ : LNRBDA staff, September 4, 2014).

The above statement also serves to buttress the 'learning' feature of PME as posited by Estrella and Gaventa (1998) who emphasized that PME, as an undertaking, has the potential to be educational, thereby creating an atmosphere for change and action. Contrastingly however, the inherent inadequacies noted in the PME process have had some negative outcomes as respondents stated that every stakeholder is not involved in decisions taken after the data collection stage of the M\&E process. Beneficiaries suggested that low participation in the post-data collection phase constitutes a barrier to progress on the project. 
Table 5: Overall level of satisfaction with PME process and increased production of crops

\begin{tabular}{|c|c|c|c|c|c|c|c|c|}
\hline \multirow{2}{*}{\multicolumn{3}{|c|}{$\begin{array}{l}\text { NAS } \\
\text { NS }\end{array}$}} & \multicolumn{5}{|c|}{$\begin{array}{l}\text { Overall level of satisfaction with the PME } \\
\text { Process }\end{array}$} & \multirow{3}{*}{$\begin{array}{l}\text { Total } \\
77\end{array}$} \\
\hline & & & \multirow{2}{*}{$\begin{array}{l}\text { SS } \\
13\end{array}$} & \multirow{2}{*}{$\begin{array}{l}S \\
44\end{array}$} & \multirow{2}{*}{$\begin{array}{l}\text { VS } \\
15\end{array}$} & \multirow[b]{2}{*}{4} & \multirow[b]{2}{*}{1} & \\
\hline Increased & No & Observed Count & & & & & & \\
\hline $\begin{array}{l}\text { proauction or } \\
\text { crops as a result }\end{array}$ & & Expected Count & $15 \cdot 7$ & 38.9 & 14.2 & 6.0 & 2.2 & 77.0 \\
\hline of the $M \& E$ & & $\%$ of Total & $12.6 \%$ & $42.7 \%$ & $14.6 \%$ & $3.9 \%$ & $1.0 \%$ & $74.8 \%$ \\
\hline & Yes & Observed Count & 8 & 8 & 4 & 4 & 2 & 26 \\
\hline & & Expected Count & $5 \cdot 3$ & 13.1 & 4.8 & 2.0 & .8 & 26.0 \\
\hline & & $\%$ of Total & $7.8 \%$ & $7.8 \%$ & $3.9 \%$ & $3.9 \%$ & $1.9 \%$ & $25.3 \%$ \\
\hline \multirow{3}{*}{\multicolumn{2}{|c|}{$\begin{array}{l}\text { Total } \\
\text { Expected Count } \\
\% \text { of Total }\end{array}$}} & Observed Count & 21 & 52 & 19 & 8 & 3 & 103 \\
\hline & & 21.0 & 52.0 & 19.0 & 8.0 & 3.0 & 103.0 & \\
\hline & & $20.4 \%$ & $50.5 \%$ & $18.4 \%$ & $7.8 \%$ & $2.9 \%$ & $100.0 \%$ & \\
\hline
\end{tabular}

The study also assessed the relationship between the PME process of the scheme and project's outcomes by exploring the beneficiaries' overall level of satisfaction with the PME process and their responses on whether they had experienced increased crop production as a result of the PME process. Table 5 presents the cross tabulation of the beneficiaries' overall level of satisfaction with the PME process and their views as to whether they had experienced increased crop production as a result of the PME process. The table indicates that 20.4 per cent of beneficiaries sampled were not at all satisfied with the PME process and 50.5 per cent were not satisfied with the PME process. In other words, 70.9 per cent of the total respondents reported that the PME process of the project was not satisfactory. On the other hand, 18.4 per cent, 7.8 per cent and 2.9 per cent of the total respondents respectively reported that they were somewhat satisfied, satisfied and very satisfied with the PME process of the project, altogether making a combined 29.1 per cent of the total respondents who were satisfied with the PME process.

With regards to crop production in the irrigation project, it is evident from Table 5 that the majority of the beneficiaries sampled ( 74.8 per cent) had not experienced increased crop production as a result of the project's PME process, while 25.3 per cent of the respondents answered in the affirmative to the same question.

Hypothesis testing is done using Fisher's exact test to ascertain if there is any significant relationship between the PME process and the project outcomes. The result of the test carried out at 5 per cent level of significance is presented in Table 6. 
Table 6: Chi-Square Tests for Overall level of satisfaction with PME process and increased production of crops

\begin{tabular}{|l|l|l|l|l|l|}
\hline & Value & Df & $\begin{array}{l}\text { Assymp. } \\
\text { Sig. } \\
(\mathbf{2} \text {-sided })\end{array}$ & $\begin{array}{l}\text { Exact Sig. } \\
(\mathbf{2} \text {-sided) }\end{array}$ & $\begin{array}{l}\text { Exact Sig. } \\
\text { (1-sided) }\end{array}$ \\
\hline Pearson Chi-Square & $10.019^{\mathrm{a}}$ & 4 & .040 & .040 & \\
\hline Likelihood Ratio & 9.61 & 4 & .053 & .069 & \\
\hline Fisher's Exact Test & 9.866 & & & .031 & \\
\hline Linear-by-Linear Association & .983 & 1 & .321 & .346 & .191 \\
\hline N of Valid Cases & 103 & & & & \\
\hline
\end{tabular}

a. 4 cells $(40.0 \%)$ have an expected count of less than 5 . The minimum expected count is .76

The result of the Fisher's exact test, shown in Table 6, reports an Exact $P$ value of (o.031). Since the P value is less than the level of significance, the null hypothesis is rejected in favour of the alternative hypothesis. There is thus a statistically significant relationship between the beneficiaries' overall level of satisfaction with the PME process and increment in crop production $(P=0.031)$. The fact that 55.3 per cent of the total respondents who were not satisfied with the PME process of the project indicated that they had not experienced increased crop production (shown in Table 15), further substantiates the notion that there exists a relationship between the PME process and project outcomes.

From the foregoing, it can be reasonably concluded that there is a relationship between the PME process of the project and project outcomes, as the non-satisfactory performance of the PME process contributed to the outcomes of the project. When asked if the PME process had contributed to an increase in crop production, a respondent stated:

Well, let me tell you something, we have more knowledge through M\&E but our crops have not increased. Our knowledge and M\&E are not enough. They are not enough to increase our harvest ( $\mathrm{P} 4$ : Beneficiary, September 3, 2014).

In line with the findings in the quantitative study, it is evident from the above response that the PME process and the overall benefits derived from it had not led to increased crop production in the Tada Shonga Irrigation Project.

It is apposite to consider other outcomes of the project that may not be connected with the PME process. Interviews conducted explored other possible outcomes of the project by asking respondents to reflect on the general outcomes of the project. Evidently, beneficiaries had benefitted from several training programmes and seminars organized 
by LNRBDA as these have been a source of knowledge acquisition for the farmers, and have improved the farming skills of the beneficiaries.

However, despite the notable increase in the knowledge and skills asset of the beneficiaries, many beneficiaries, rather than produce in commercial quantities, were still producing for subsistence. This much was realized through the analysis of respondents' responses. One respondent described the situation by saying:

.We ensure that they are able to produce rice that would meet the subsistence need of the family; even though if it cannot go a long way to be commercialized ( $\mathrm{P}_{1}$ : LNRBDA staff, September 3, 2014).

Evidently, the majority of the beneficiaries were still producing to feed their families. This contradicts the intention of the project which aims at producing rice in commercial quantities in order to stem rice importation to Nigeria. It thus becomes imperative to probe further the reasons behind the inability to meet the objectives of the project. The study thus examined the reason for the failure by considering other possible factors affecting the outcomes of the Tada Shonga Irrigation Project apart from the PME process that had mixed outcomes on the scheme.

Generally, the comments and feedback gathered suggest that one of the main reasons for the inability to meet the project objectives has been the incidence of flood and its effect on farmland and rice production. One respondent captured the situation, saying:

I think 2008/2009, they had a flood that was so devastating that it encroached and submerged all the 3,200 hectares that the farmers couldn't even hold a grain of rice... (in) 2010, we experienced flood again, we the authority have two arrangement; we have over 140 hectares of rice that we planted in a PPP (Public-Private Partnership) arrangement with the farmers, we gave them the credit facilities. We have er, investor that also came to farm more than 100 hectares and they were swept-off by the flood (P2: LNRBDA staff, September 3, 2014).

It is evident from the above quote that the outcome of the project had been adversely affected by the incidence of flooding which made it extremely difficult to commercialize the initiative, and had negatively affected the motivation of the farmers. It can be said that the fear of flooding is the beginning of scepticism in cultivation for Tada Shonga Irrigation farmers.

Also, the slow or unsatisfactory pace of construction work at the irrigation site was having an adverse effect on the fulfilment of project objectives. The contract for the construction of the irrigation site and facilities which was initially awarded in 2006 
was cancelled and re-awarded to another construction firm in 2010. The progress that LNRBDA and beneficiaries can make on the farm sites was therefore dependent on the progress recorded in the construction work by the contractor, as more plots are put to use whenever there is progress on the construction work. This undoubtedly hindered the fulfilment of project objectives as beneficiaries cannot cultivate more than the available facilities. Furthermore, inadequate capital also served as a constraint to the fulfilment of project objectives, as a respondent stated:

It is true that money is a problem. Even if I get more land, what can I do with it since I don't have enough money to cultivate the land? (P5: Beneficiary, September 4, 2014).

The above comment is indicative of the fact that beneficiaries lacked access to financial capital. Evidently, the lack of financial capital had limited the amount of land utilized by beneficiaries, hence curtailing progress towards the commercialisation of agricultural production.

\section{Conclusion and Recommendations}

The analysis of the outcome of the project and its PME process, which was done through the computation of the Outcome Perception Index (OPI), reveals that the project and its PME process had mixed outcomes. The beneficiaries indicated an increase in such outcome measures as the confidence to approach extension workers to share their problems, thoughts and opinions; ability to solve agricultural problems through experimentation; and farmer organisations' ability to influence project outcomes. These are all consistent with the findings of Njuki et al. (2008), Holte-McKenzie et al. (2006) and Ferreyra and Beard (2007). Furthermore, the analysis indicates that there had been migration of people to the project area, while there have also been positive changes in the way beneficiaries utilize natural resources as a result of M\&E. Contrastingly however, the study found that the PME process in particular and the project in general did not result in a considerable increase in crop production and the land area used for agricultural production. Consequently, the project did not improve the lives of the beneficiaries and their households in a significant manner.

An examination of the relationship between PME process and project outcomes through the assessment of the association between beneficiaries' overall levels of satisfaction with the PME process and increment in crop production established that there was a significant relationship between beneficiaries' overall levels of satisfaction with the PME process and increment in crop production. Hence, there is a relationship between the PME process of the project and project outcomes as the deficient PME process inadvertently contributed to the outcomes of the project. It is noteworthy that the 
relationship is indicative, rather than proof of a possible causal relationship as there are other factors that affected the outcomes of the project. Chief among the other factors affecting project outcomes is the incessant incidence of flooding that has swept away a considerable amount of land cultivated by the beneficiaries. Also, the slow pace of construction work and lack of (access to) financial capital adversely affected projected outcomes.

Based on the findings of the study, it is essential to establish a PME process that is entirely participatory, from the initial design of the PME through to the decisions taken based on the PME process. Also, beneficiaries must engage with the PME process with the aim of benefitting from the process. As Tandon (1966) rightly affirms that rights and benefits can be secured through the active struggle for them, it is important that beneficiaries, especially through the farmers' associations, actively channel their efforts in demanding their active participation in the entire stages of the PME process so as to secure benefits from the process.

Furthermore, it is crucial that collaboration among farmers be strengthened. Even as the study pointed out that farmers were collaborating to learn new skills and techniques, avenues for the foregoing collaboration must be promoted by the farmers as well as the implementing agency. Another means to achieve this, aside from the PME process, is through the use of the opportunities/space created in the farmer training programme.

The findings also revealed that lack of financial capital adversely affected efforts to commercialize rice production in the Tada Shonga Irrigation Project. It is expedient that government expands access to credit facilities for farmers through the provision of low interest loans to boost agricultural production in the scheme. Also, the scope and reach of micro-finance institutions in Nigeria should be expanded to better cater for rural farmers. Savings could also be encouraged among farmers by making a provision whereby farmers have regular contributory savings in either the micro-finance institutions or through the establishment of farmers' cooperative societies in order to access loans.

There is no gainsaying the fact that the slow pace of construction work at the Tada Shonga Irrigation Project contributed to the high incidence of flooding recorded in the area, and consequently to the failure to meet project objectives. Government must thus put in place the necessary measures and policies to ensure the timely completion of construction projects. As a solution to the slow pace of construction work, it is important that the stringent monitoring of projects and construction work be put in place by the government in order to regularly check progress against plans. Although there are M\&E units in both the FMWR and LNRBDA, the strengthening of the capacity of both units with the necessary personnel and equipment in order to adequately monitor progress of 
the entities' projects is needful. Finally, and in a bid to ensure project success in Nigeria, it is essential that PME be ebbed in policies, as failure of projects is aided by the lack of emphasis of PME in policies that relate to project management.

\section{References}

Aczel, A. D. and J. Sounderpandian (2009). Complete business Statistics. McGraw-Hill.

Adebayo, K., S. Babu and V. Rhoe (2009). Institutional capacity for designing and implementing agriculltural and rural development policies. Nigeria Strategy Support Programme (NSSP) Background Paper oo8.

Afon, A. O. (2009). Residents and the development control agency: A perceptual study of two local planning authorities. Ife Journal of Environmental Design Management, 2(1), pp. 44-54.

Akindele, S. T. and A. Adebo (2004). The political economy of river basin and rural .development authority in Nigeria: A retrospective case Study of Owena-River Basin and Rural Development Authority (ORBRDA). Journal of Human Ecology, pp. $55-62$.

Alejandro Leal, P. (2007). Participation: The ascendancy of a buzzword in the neo-liberal era. Development in Practice, 17(4-5), pp. 539-48.

Anyanwu, J. C. (2012). Why does foreign direct investment go where it goes?: New. evidence from African countries. Annals of Economics and Finance, 13(2): pp. 425-62.

Azuibuike, L. O. (2009). Privatization and foreign investments in Nigeria. Florida: BrownWalker Press.

Babbie, E. and J. Mouton, (2001). The practice of social research.

Bayer, W. and A.Waters-Bayer (2002) Participatory monitoring and evaluation (PM\&E) with pastoralists: A review of experience and annotated bibliography. Eschborn: GTZ $\mathrm{GmbH}$.

Blauert, J.and E. Quitanar (2000). Seeking local indicators: Participatory stakeholder evaluation of farmenr-to-farmer projects, Mexico. In M. Estrella, J. Blauert, D. Campilan, J. Gaventa, J. Gonsalves, I. Guijt, D. Johnson and R. Ricafort (eds.), Learning from change: Issues and experiences in participation monitoring and evaluation, pp. 32-49. London: Intermediate Technology Publications. 
Bradley, J. E., M. V. Mayfield, M. P. Mehta and A.Rukonge (2002). Participatory evaluation of reproductive health care quality in Developing Countries. Social Science \& Medicine .55(2), pp. 269-82.

British Council (2012). Gender in Nigeria. British Council.

Bryan, M. F. and S.G.Cecchetti (1993). The consumer price index as a measure of inflation. National Bureau of Economic Research.

Chouinard, J. A. (2013). The case for participatory evaluation in an era of accountability. American Journal of Evaluation, 34(2), pp. 237-53.

Cramb, R.A., T. Purcell and T.C. Ho (2004). Participatory assessment of rurallivelihoods in the central highlands of Vietnam. Agricultural Systems 81(3), pp. 255-72.

Cullen, A. E., C. L. Coryn and J. Rugh (2011). The politics and consequences of Including stakeholders in international development evaluation. American Journal of Evaluation .32(3), pp. 345-61.

Daneji, M. I. (2011). Agricultural development intervention programmes in Nigeria (1960 To Date): A Review. Savannah Journal of Agriculture, 6(1), pp. 101-07.

Deutsche Bank Research. (2014). Nigeria:The No. 1 African Economy. Research Briefing: Emerging Markets. http://www.dbresearch.com (accessed 6 June 2014)

Dinbabo, F. M. (2005). Indigenous community based Organizations (CBOs), the community .and local development: A case study of Gubre in Ethiopia. Unpublished Master's Thesis. Germany: Institute of Development Research and Development Policy, Ruhr University.

Douthwaite, B., S. Schulz, A. S. Olanrewaju and J. Ellis-Jones (2007). Impact pathway evaluation of an integrated striga hermonthica control project in Northern Nigeria Agricultural Systems 92(1), pp. 201-22.

Estrella, M. (2000). Learning from Change. In M. Estrella, J. Blauert, D. Campilan, J. Gaventa, .J. Gonsalves, I. Guijt, D. Johnson and R. Ricafort (eds.), Learning from change: Issues and experiences in participation monitoring and evaluation, pp. 1-14. London: .Intermediate Technology Publications.

Estrella, M. and J. Gaventa (1998). Who counts reality? Participatory monitoring and evaluation: A iiterature review. Sussex: Institute of Development Studies Working Paper 70. 
Federal Ministry of Water Resources (FMWR). (2006). http://enplan.org/ tadashongarice.pdf. Accessed 5th August, 2013.

Ferreyra, C. and P. Beard (2007). Participatory evaluation of collaborative and integrated water management: Insights from the field. Journal of Environmental Planning and Management, 50(2), pp. 271-96.

Franzel, S. N., S. Wangia and J. Dewolf (2008). Collaborative monitoring and evaluation: assessing the uptake of improved fallows and bomass transfer in Western Kenya. Experimental Agriculture 44(1), pp. 113-27.

Fraser, E. D., A. J. Dougill, W. E. Mabee, M. Reed and P. McAlpine (2006). Bottom up and top down: Analysis of participatory processes for sustainability indicator identification as a pathway to community empowerment and sustainable environmental management. Journal of Environmental Management, pp. 114-127.

Freire, P. (2000). Pedagogy of the oppressed Continuum International Publishing Group.

Green, M. (2003). Globalizing development in Tanzania policy franchising through participatory project management. Critique of Anthropology, 23(2), pp. 123-43.

Gunda, C., J. Gasasira, S. Sizthole, H. Liversage and S. Jonckheere (2013). Securing smallholder farmers' land and water rights and promoting equitable land access in irrigation and watershed management in Malawi, Rwanda and Swaziland. Annual World Bank Conference on Land and Poverty. Washignton D. C.: World Bank Publications.

Hacker, J. S., G. A. Huber, A. Nichols, P. Rehm, M. Schlesinger, R. Valletta and S. Craig (2013). The economic security index: A new measure for research and policy analysis. Review of Income and Wealth 6o(S1), pp. S5-S32

Heck, N., P. Dearden, A. McDonald, and S. Carver (2011). Stakeholder opinions on the assessment of MPA effectiveness and their interests to participate at Pacific Rim National Park Reserve, Canada. Environmental Management 47, pp. 603-16.

Holte-McKenzie, M., S. Forde and S. Theobald (2006). Development of a participatory monitoring and evaluation strategy. Evaluation and Program Planning 29(4), pp. 36576.

Ijaiya, G. (2006). Participatory development and project performance in Nigeria: An assessment of the existing DFRRI Borehole Water Projects in Offa, Kwara State. Geo-Studies Forum 3(1\&2). 
International Fund for Agricultural Development (IFAD). (2009). IFAD Programme Bulletin for Nigeria. http://ifad.org. Accessed 3rd March, 2011.

Jacobs, A., C. Barnett, and R. Ponsford (2010). Three approaches to monitoring: Feedback systems, participatory monitoring and evaluation and logical frameworks. IDS Bulletin .41(6), pp. 36-44.

Mathie, A. and J. C. Greene (1997). Stakeholder participation in evaluation: How important is diversity? Evaluation and Program Planning 20(3), pp. 279-285.

Mehta, C. R. and N. R. Patel (2011). IBM SPSS Exact Tests. IBM Corporation.

Mouton, J. (2001). How to succeed in your master's and doctoral studies: A South African .guide and resource book. Van Schaik.

National Bureau of Statistics (NBS). (2010). The Nigeria Poverty Profile 2010 Report. Abuja: National Bureau of Statistics.

National Bureau of Statistics (NBS). (2013). Economic eutlook for the Nigerian Economy (.2013-2016). Abuja: National Bureau of Statistics.

National Bureau of Statistics (NBS). (2014). Measuring better: Presentation of preliminary results of the rebased Nominal Gross Domestic Product (GDP) estimates for Nigeria 2010 to 2013. Abuja: National Bureau of Statistics. http://www.nigerianstat.gov.ng Accessed 25th May 2014.

Njuki, J., M. Mapila, S. Kaaria and T. Magombo. (2008). Using community indicators for .evaluating research and development programmes: Experiences from Malawi. Development in Practice 18(4-5), pp. 633-42.

Ojha, H., J. Cameron and B. Bhattarai (2005). Understanding development through the language of Habermas and Bourdieu: Insights from Nepal's leasehold forestry programme. International Development Planning Review 27(4), pp. 479-97.

Rahnema, M. (1990). Participatory action research: The last temptation of saint development. .Alternatives: Global, Local, Political 15(2), pp. 199-226.

Slocum, R., L. Wichhart, D. Rocheleau, and B. Thomas-Slayter (1995). Power, process and participation: Tools for change. London: Intermediate Technology Publications Ltd.

Tandon, Y. (1996). Poverty, process of impoverishment and empowerment. In V. Titi and N. Singh, Empowerment for sustainable development: Toward operational strategies. London: Zed Books. 
United Nations Development Programme (UNDP). (2002). Handbook on monitoring and evaluation for results. New York: United Nations Development Programme.

Vernooy, R., S. Qiu and J. Xu (2003). Voices for change: Participatory monitoring and evaluation in China. Ottawa: International Development Research Centre.

Wharton, A. S. and J. N. Baron (1987). So happy together? The impact of gender segregation on men at work. American Sociological Review 52(5), pp. 574-587.

World Bank. (2013) The Nigeria Economic Report. World Bank Publications.

Zerfu, E. and S. W. Kebede (2013). Filling the learning gap in programme implementation using participatory monitoring and evaluation: Lessons from farmer field schools in Zanzibar. International Food Policy Research Institute. 